\title{
CHARACTERISTICS OF PRIMARY GLAUCOMA IN EYE OUTPATIENT CLINIC OF RA BASOENI HOSPITAL, MOJOKERTO, INDONESIA
}

\author{
Awina Rayungsista \\ RA Basoeni General Hospital, Mojokerto, Indonesia
}

\section{ABSTRACT}

Glaucoma is the third cause of blindness after cataracts and refractive disorders. About 4.5 million people worldwide suffer from blindness due to primary glaucoma. A study on the characteristics of primary glaucoma in Eye Outpatient Clinic at RA Basoeni Mojokerto Hospital in the period of January-December 2016 had been performed in a descriptive cross sectional retropective study, observing: glaucoma type, gender, age, laterality, visual acuity, and intra ocular pressure (IOP). The type of primary glaucoma that most patients experienced was primary angle closure glaucoma. In primary open-angle glaucoma, the number of male patients was almost the same as female patients. Whereas, in primary angle closure glaucoma, there were more female patients than male. Primary glaucoma patients, both open and closed, were mostly >60 years old. Both primary open and angle closure glaucoma occurred mostly bilaterally. The highest visual acuity of primary glaucoma patients was mild vision loss and near-total vision loss. More glaucoma patients had IOP >21 $\mathrm{mmHg}$, both in right and left eye.

Keywords: Glaucoma; characteristics; type of glaucoma; gender; age; laterality; visual acuity; IOP

\section{ABSTRAK}

Glaukoma merupakan penyebab kebutaan ketiga setelah katarak dan kelainan refraksi. Sekitar 4,5 juta orang di seluruh dunia menderita kebutaan akibat glaukoma primer. Telah dilakukan penelitian mengenai karakteristik glaukoma primer di Poli Mata RSUD RA Basoeni Mojokerto periode Januari-Desember 2016 meliputi: jenis glaukoma, jenis kelamin, usia, lateralitas, tajam penglihatan, dan tekanan intra okular (TIO) secara deskripsi retropektif cross sectional. Jenis glaukoma primer terbanyak yang dialami pasien adalah glaukoma sudut tertutup primer. Pada glaukoma sudut terbuka primer, jumlah pasien laki-laki hampir sama pasien perempuan. Sedangkan, pada glaukoma sudut tertutup primer, didapatkan lebih banyak pasien perempuan daripada laki-laki. Pasien glaukoma primer, baik sudut terbuka maupun tertutup, paling banyak berada pada rentang usia > 60 tahun. Baik glaukoma sudut terbuka maupun tertutup primer, paling banyak terjadi bilateral. Tajam penglihatan pasien glaukoma primer paling banyak adalah mild vision loss dan near-total vision loss. Pasien glaukoma lebih banyak memiliki TIO >21 mmHg, baik mata kanan maupun mata kiri.

Kata kunci: Glaukoma; karakteristik; jenis glaukoma; jenis kelamin; usia; lateralitas; tajam penglihatan; TIO

Correspondence: Awina Rayungsista, RA Basoeni Hospital, Mojokerto. Phone: (+62) 81358449829. E-mail: dr.rayung@gmail.com

pISSN:2355-8393 • eISSN: 2599-056x • doi: http://dx.doi.org/10.20473/fmi.v54i3.10007

- Fol Med Indones. 2018;54:172-178 • Received 26 Sep $2017 \bullet$ Accepted 8 Mar 2018

- Open access under CC-BY-NC-SA license • Available at https://e-journal.unair.ac.id/FMI/

\section{INTRODUCTION}

Glaucoma is an eye disease characterized by glaucomatous excavation, optic nerve neuropathy, and distinct visual field damage and is mainly due to abnormal intra ocular pressure (IOP) (Ilyas et al 2002). Glaucoma is the third cause of blindness after cataracts and refractive disorders (WHO 2014). About 4.5 million people worldwide suffer from blindness due to primary glaucoma. This amount is more than $12 \%$ when compared to the total number of global blindness (Ilyas et al 2002). According to the American Academy of Ophthalmology Staff (2016), risk factors that affect primary open-angle glaucoma include: IOP, old age, race, thin central cornea, a history of family disease, and myopia. Whereas, risk factors for primary angle closure glaucoma include race, ocular biometry, gender, family history, and refractive disorders.

IOP is determined by the rate of the formation of aqueous humor and resistance to its flowing out of the eye. Aqueous humor is produced by the ciliary body. Aqueous humor flows from the eye chamber behind the pupil to the anterior chamber and then to the trabecular meshwork in the anterior angle chamber (Riordan-Eva 2009). In the normal eye, a non-trabecular outflow is 
called uveoscleral outflow. Various mechanisms may be involved in this process, but the main mechanism is the flow of aquos from the anterior chamber into the ciliary muscle and then into the supraciliary and supracoroidal spaces. The aqueous humor then comes out of the eye through the intact sclera or through the nerves and blood vessels that penetrate it (American Academy of Ophthalmology Staff 2016).

The main mechanism of decreased vision in glaucoma is apoptosis of the retinal ganglion cells which causes thinning of the layers of nerve fibers and the inner lining of the retina and reduced axons in the optic nerve. The optical disc becomes atrophic, accompanied by the enlargement of the optic cup (Riordan-Eva 2009). There are several factors believed to cause death of retinal ganglion cells (RGC). According to various theories, the factors of increased IOP and vascular dysregulation are the main causes of glaucomatous atrophy in the form of blockages in axoplasmic flow in RGC axons in lamina cribrosa, altering the optic nerve microcirculation at lamina levels and changes in laminar glial tissue and connective tissue (Agarwal et al 2009).

\section{MATERIALS AND METHODS}

Data on all primary glaucoma patients aged over 38 years who were treated at the Eye Outpatient Clinic at RA Basoeni Hospital, Mojokerto, Indonesia, from January to De-cember 2016 were collected in this study. The data were obtained by the author from medical records, including types of glaucoma, gender, age, laterality, visual acuity, and IOP. The type of the study was a descriptive cross-sectional retrospective study with secondary data on the glaucoma patients at Eye Outpatient Clinic, RA Basoeni Hospital, Mojokerto. The number of patients enrolled as glauco-ma patients in the clinic was 47 , comprising 21 males and 26 females.

\section{RESULTS}

Frequency distribution of primary glaucoma based on the type of glaucoma in this study showed that primary open angle glaucoma patients were 21 (44.7\%), and those with primary angle closure glaucoma were 26 $(55.3 \%)$. The number of male patients with primary open angle glaucoma was almost the same as the female patients. Whereas, in primary angle closure glaucoma, there were more female patients than males (61.5\%).

Most of the patients of both primary and open-angle glaucoma were in the age of $>60$ years. In primary open angle glaucoma, they were $61.9 \%$ and in primary angle closure glaucoma, they were $42.3 \%$. Laterality in primary open angle glaucoma was mostly bilateral $(66.7 \%)$, and so was in primary angle closure glaucoma $(57.7 \%)$. Of the 76 eyes affected by glaucoma, the visual acuity was mostly mild vision loss and near-total vision loss $(22.4 \%)$ and the least was moderate vision loss $(3.9 \%)$. In this study, 47 patients suffered from primary glaucoma and 76 eyes of these patients had glaucoma. Of these, only 22 eyes had IOP between 10 $21 \mathrm{mmHg}(28.9 \%)$ and the rest had IOP > $11 \mathrm{mmHg}$ $(71.1 \%)$.

Table 1. Frequency distribution of primary glaucoma based on sex

\begin{tabular}{cccc}
\hline Sex & $\begin{array}{c}\text { Primary open- } \\
\text { angle glaucoma }\end{array}$ & $\begin{array}{c}\text { Primary angle } \\
\text { closure glaucoma }\end{array}$ & Total \\
\hline Male & $11(52.4 \%)$ & $10(38.5 \%)$ & $21(44.7 \%)$ \\
Female & $10(47.6 \%)$ & $16(61.5 \%)$ & $26(55.3 \%)$ \\
\hline Total & 21 & 26 & 47 \\
\hline
\end{tabular}

Table 2. Frequency distribution of primary glaucoma based on age

\begin{tabular}{cccc}
\hline Age (years old) & $\begin{array}{c}\text { Primary open-angle } \\
\text { glaucoma }\end{array}$ & $\begin{array}{c}\text { Primary angle closure } \\
\text { glaucoma }\end{array}$ & Total \\
\hline $36-40$ & $1(4.8 \%)$ & $1(3.8 \%)$ & $2(4.3 \%)$ \\
$41-45$ & $0(0 \%)$ & $1(3.8 \%)$ & $1(2.1 \%)$ \\
$46-50$ & $3(14.3 \%)$ & $2(7.7)$ & $5(10.6 \%)$ \\
$51-55$ & $2(9.5 \%)$ & $2(7.7 \%)$ & $4(8.5 \%)$ \\
$55-60$ & $2(9.5 \%)$ & $9(34.7 \%)$ & $11(23.4 \%)$ \\
$>60$ & $13(61.9 \%)$ & $11(42.3 \%)$ & $24(51.1 \%)$ \\
\hline Total & 21 & 26 & 47 \\
\hline
\end{tabular}


Table 3. Frequency distribution of primary glaucoma based on laterality

\begin{tabular}{cccc}
\hline Laterality & $\begin{array}{c}\text { Primary open-angle } \\
\text { glaucoma }\end{array}$ & $\begin{array}{c}\text { Primary angle } \\
\text { closure glaucoma }\end{array}$ & Total \\
\hline Right eye & $2(9.5 \%)$ & $8(30.8 \%)$ & $10(21.3 \%)$ \\
Left eye & $5(23.8 \%)$ & $3(11.5 \%)$ & $8(17 \%)$ \\
Bilateral & $14(66.7 \%)$ & $15(57.7 \%)$ & $29(61.7 \%)$ \\
\hline Total & 21 & 26 & 47 \\
\hline
\end{tabular}

Table 4. Frequency distribution of primary glaucoma based on visual acuity

\begin{tabular}{|c|c|c|c|c|c|c|c|c|c|}
\hline \multirow{3}{*}{$\begin{array}{l}\text { Classification } \\
\text { of visual } \\
\text { acuity }\end{array}$} & \multicolumn{4}{|c|}{ Primary open-angle glaucoma } & \multicolumn{4}{|c|}{ Primary angle closure glaucoma } & \multirow{3}{*}{ Total } \\
\hline & \multicolumn{2}{|c|}{ Unilateral } & \multicolumn{2}{|c|}{ Bilateral } & \multicolumn{2}{|c|}{ Unilateral } & \multicolumn{2}{|c|}{ Bilateral } & \\
\hline & Right & Left & Right & Left & Right & Left & Right & Left & \\
\hline $\begin{array}{l}\text { Normal } \\
\text { vision }\end{array}$ & $\begin{array}{c}0 \\
(0 \%)\end{array}$ & $\begin{array}{c}2 \\
(40 \%)\end{array}$ & $\begin{array}{c}1 \\
(7.1 \%)\end{array}$ & $\begin{array}{c}3 \\
(21.4 \%)\end{array}$ & $\begin{array}{c}1 \\
(12.5 \%)\end{array}$ & $\begin{array}{c}2 \\
(66.67 \%)\end{array}$ & $\begin{array}{c}2 \\
(13.3 \%)\end{array}$ & $\begin{array}{c}4 \\
(26.7 \%)\end{array}$ & $\begin{array}{c}15 \\
(19.7 \%)\end{array}$ \\
\hline $\begin{array}{l}\text { Mild vision } \\
\text { loss }\end{array}$ & $\begin{array}{c}0 \\
(0 \%)\end{array}$ & $\begin{array}{c}2 \\
(40 \%)\end{array}$ & $\begin{array}{c}3 \\
(21.4 \%)\end{array}$ & $\begin{array}{c}4 \\
(28.6 \%)\end{array}$ & $\begin{array}{c}1 \\
(12.5 \%)\end{array}$ & $\begin{array}{c}0 \\
(0 \%)\end{array}$ & $\begin{array}{c}4 \\
(26.7 \%)\end{array}$ & $\begin{array}{c}3 \\
(20 \%)\end{array}$ & $\begin{array}{c}17 \\
(22.4 \%)\end{array}$ \\
\hline $\begin{array}{l}\text { Moderate } \\
\text { vision loss }\end{array}$ & $\begin{array}{c}0 \\
(0 \%)\end{array}$ & $\begin{array}{c}0 \\
(0 \%)\end{array}$ & $\begin{array}{c}0 \\
(0 \%)\end{array}$ & $\begin{array}{c}1 \\
(7.1 \%)\end{array}$ & $\begin{array}{c}0 \\
(0 \%)\end{array}$ & $\begin{array}{c}0 \\
(0 \%)\end{array}$ & $\begin{array}{c}0 \\
(0 \%)\end{array}$ & $\begin{array}{c}2 \\
(13.3 \%)\end{array}$ & $\begin{array}{c}3 \\
(3.9 \%)\end{array}$ \\
\hline $\begin{array}{l}\text { Severe } \\
\text { vision loss }\end{array}$ & $\begin{array}{c}0 \\
(0 \%)\end{array}$ & $\begin{array}{c}0 \\
(0 \%)\end{array}$ & $\begin{array}{c}2 \\
(14.3 \%)\end{array}$ & $\begin{array}{c}1 \\
(7.1 \%)\end{array}$ & $\begin{array}{c}1 \\
(12.5 \%)\end{array}$ & $\begin{array}{c}0 \\
(0 \%)\end{array}$ & $\begin{array}{c}2 \\
(13.3 \%)\end{array}$ & $\begin{array}{c}1 \\
(6.7 \%)\end{array}$ & $\begin{array}{c}7 \\
(9.2 \%)\end{array}$ \\
\hline $\begin{array}{l}\text { Profound } \\
\text { vision loss }\end{array}$ & $\begin{array}{c}0 \\
(0 \%)\end{array}$ & $\begin{array}{c}0 \\
(0 \%)\end{array}$ & $\begin{array}{c}2 \\
(14.3 \%)\end{array}$ & $\begin{array}{c}0 \\
(0 \%)\end{array}$ & $\begin{array}{c}0 \\
(0 \%)\end{array}$ & $\begin{array}{c}0 \\
(0 \%)\end{array}$ & $\begin{array}{c}0 \\
(0 \%)\end{array}$ & $\begin{array}{c}2 \\
(13.3 \%)\end{array}$ & $\begin{array}{c}4 \\
(5.3 \%)\end{array}$ \\
\hline $\begin{array}{l}\text { Near-total } \\
\text { vision loss }\end{array}$ & $\begin{array}{c}0 \\
(0 \%)\end{array}$ & $\begin{array}{c}1 \\
(20 \%)\end{array}$ & $\begin{array}{c}4 \\
(28.6 \%)\end{array}$ & $\begin{array}{c}4 \\
(28.6 \%)\end{array}$ & $\begin{array}{c}2 \\
(25 \%)\end{array}$ & $\begin{array}{c}1 \\
(33.3 \%)\end{array}$ & $\begin{array}{c}3 \\
(20 \%)\end{array}$ & $\begin{array}{c}2 \\
(13.3 \%)\end{array}$ & $\begin{array}{c}17 \\
(22.4 \%)\end{array}$ \\
\hline $\begin{array}{l}\text { Total vision } \\
\text { loss }\end{array}$ & $\begin{array}{c}2 \\
(100 \%)\end{array}$ & $\begin{array}{c}0 \\
(0 \%)\end{array}$ & $\begin{array}{c}2 \\
(14.3 \%)\end{array}$ & $\begin{array}{c}1 \\
(7.1 \%)\end{array}$ & $\begin{array}{c}3 \\
(37.5 \%)\end{array}$ & $\begin{array}{c}0 \\
(0 \%)\end{array}$ & $\begin{array}{c}4 \\
(26.7 \%)\end{array}$ & $\begin{array}{c}1 \\
(6.7 \%)\end{array}$ & $\begin{array}{c}13 \\
(17.1 \%)\end{array}$ \\
\hline Total & 2 & 5 & 14 & 14 & 8 & 3 & 15 & 15 & 76 \\
\hline
\end{tabular}

Table 5. Frequency distribution of primary glaucoma based on IOP

\begin{tabular}{|c|c|c|c|c|c|c|c|c|c|}
\hline \multirow{3}{*}{$\begin{array}{c}\text { TIO } \\
\text { (mmHg) }\end{array}$} & \multicolumn{4}{|c|}{ Primary open-angle glaucoma } & \multicolumn{4}{|c|}{ Primary angle closure glaucoma } & \multirow{3}{*}{ Total } \\
\hline & \multicolumn{2}{|c|}{ Unilateral } & \multicolumn{2}{|c|}{ Bilateral } & \multicolumn{2}{|c|}{ Unilateral } & \multicolumn{2}{|c|}{ Bilateral } & \\
\hline & Right & Left & Right & Left & Right & Left & Right & Left & \\
\hline $10-21$ & $\begin{array}{c}1 \\
(50 \%)\end{array}$ & $\begin{array}{c}1 \\
(25 \%)\end{array}$ & $\begin{array}{c}1 \\
(7.1 \%)\end{array}$ & $\begin{array}{c}3 \\
(21.4 \%)\end{array}$ & $\begin{array}{c}1 \\
(1.25 \%)\end{array}$ & $\begin{array}{c}2 \\
(6.67 \%)\end{array}$ & $\begin{array}{c}5 \\
(33.3 \%)\end{array}$ & $\begin{array}{c}8 \\
(53.3 \%)\end{array}$ & $\begin{array}{c}22 \\
(28.9 \%)\end{array}$ \\
\hline$>21$ & $\begin{array}{c}1 \\
(50 \%)\end{array}$ & $\begin{array}{c}4 \\
(75 \%) \\
\end{array}$ & $\begin{array}{c}13 \\
(92.8 \%) \\
\end{array}$ & $\begin{array}{c}11 \\
(78.6 \%) \\
\end{array}$ & $\begin{array}{c}7 \\
(8.75 \%) \\
\end{array}$ & $\begin{array}{c}1 \\
(33.3 \%) \\
\end{array}$ & $\begin{array}{c}10 \\
(66.6 \%) \\
\end{array}$ & $\begin{array}{c}7 \\
(46.7 \%) \\
\end{array}$ & $\begin{array}{c}54 \\
(71.1 \%) \\
\end{array}$ \\
\hline Total & 2 & 5 & 14 & 14 & 8 & 3 & 15 & 15 & 76 \\
\hline
\end{tabular}

\section{DISCUSSION}

This was a cross sectional retrospective descriptive study to determine the characteristics of glaucoma patients in Eye Cinic at RA Basoeni Hospital, Mojokerto from January to December 2016 using secondary data. The number of glaucoma patients in the Eye Outpatient Clinic at RA Basoeni Hospital, Mojokerto during this period was 47 people.

Examination of the anterior chamber angle of the eye in Eye Outpatient Clinic at RA Basoeni Hospital, Mojokerto was done using slit lamp with the Van Herick method. Based on glaucoma type classification, research data showed that primary angle closure glaucoma patients were in higher number than the patients with primary open angle glaucoma. This is consistent with a previous study conducted by Quigley in 2006 which showed that the incidence of primary angle closure glaucoma in Asian races was higher than European. The results of the meta-analysis also showed that the highest type of glaucoma experienced by Asians is the primary angle closure as much as $0.75 \%$ (Cheng et al 2014). This is due to the presence of plateau configuration in the iris of the Chinese. There were $3.8 \%$ Europeans with eyes that had PC angle $<2$ degrees on gonioscopic examination using the Shaffer system in Farmingham's study. Whereas, in a study in a clinic in 
the United States, there were $47.8 \%$ of Vietnamese people of the same age group who had similar examination results. In a hospital study comparing angular configurations examined in healthy Southeast Asian, African-American and Caucasians in the United States with a gonioscopic examination using the Spaeth system, it was found that the iris insertion in Asians was more anterior compared to that in whites and blacks, although Asian subjects were younger and sufferred from myopia.

As for the results of the study, most primary angle closure glaucoma patients were female, which were 16 persons from 26 patients. This is in accordance with the meta-analysis of Cheng which found that generally, glaucoma is affected more in women (Cheng et al 2014). The cause of women suffering more from glaucoma, especially angle closure glaucoma, is the short axis of the eye, hormonal factors, pregnancy, and shallow anterior chamber in the eye (Tehrani 2014). In primary open-angle glaucoma patients there were no significant differences between men and women. These results are similar to a study conducted by Tielsch et al (1991) and Klein et al (1992).

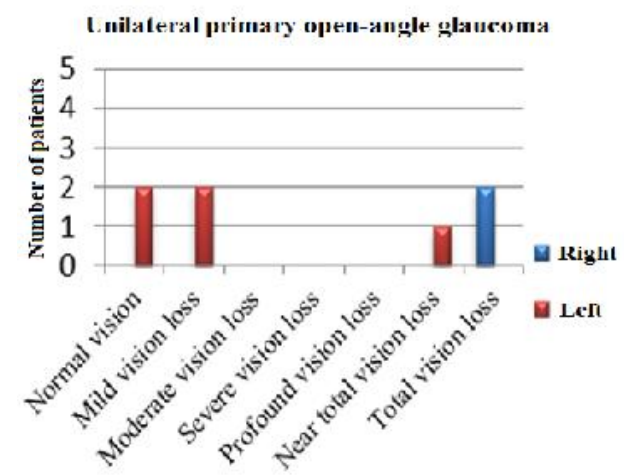

Fig. 1. Unilateral primary open-angle glaucoma patients based on sharp visual acuity.

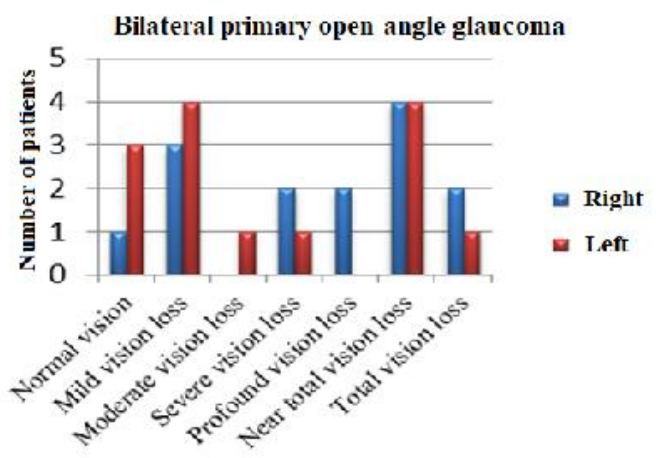

Fig. 2. Bilateral primary open-angle glaucoma patients based on visual acuity.

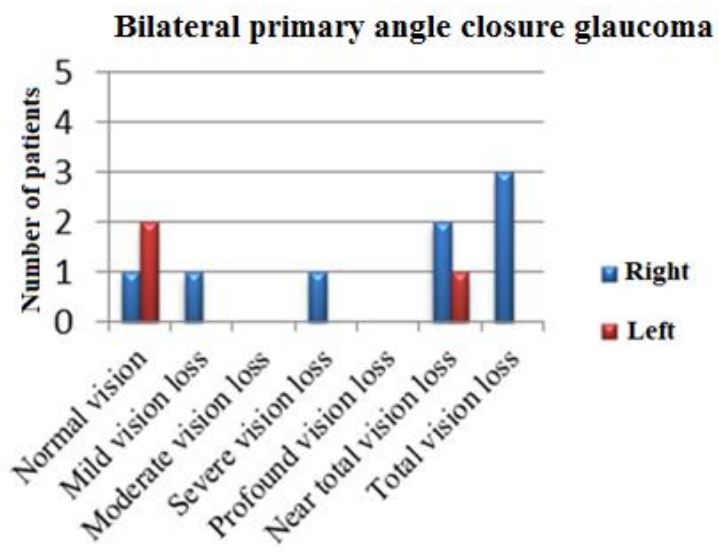

Fig. 3. Unilateral primary angle closure glaucoma patients based on visual acuity.

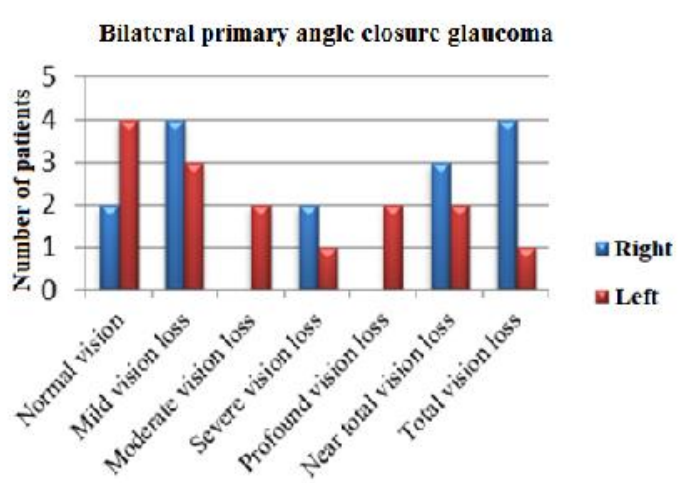

Fig. 4. Bilateral primary angle closure glaucoma patients based on visual acuity.

\section{Unilateral primary open-angle glaucoma}

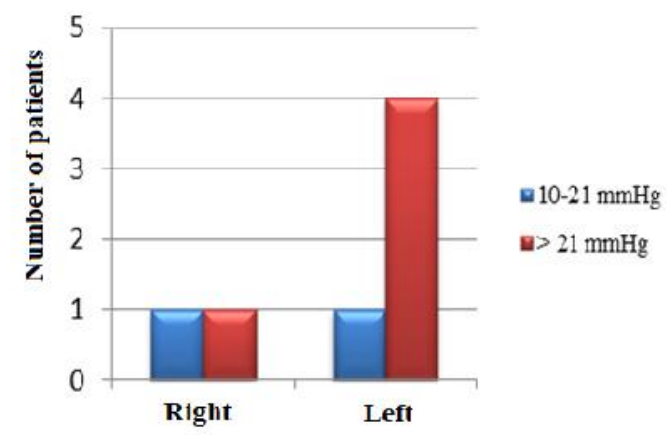

Fig. 5. Unilateral primary open angle glaucoma patients based on IOP.

In this study, the highest number of primary glaucoma patients was found at over 60 years of age, as many as 24 patients $(51.1 \%)$, in which 13 patients had primary open angle glaucoma and 11 primary angle closure glaucoma. This is consistent with the study of Cheng et 
al in 2014. In this study it was found that $0.21 \%$ of patients aged 40-49 years, $0.54 \%$ aged 50-59 years, $1.26 \%$ aged $60-69$ years and $2.32 \%>70$ years old.

\section{Bilateral primary open-angle glancoma}

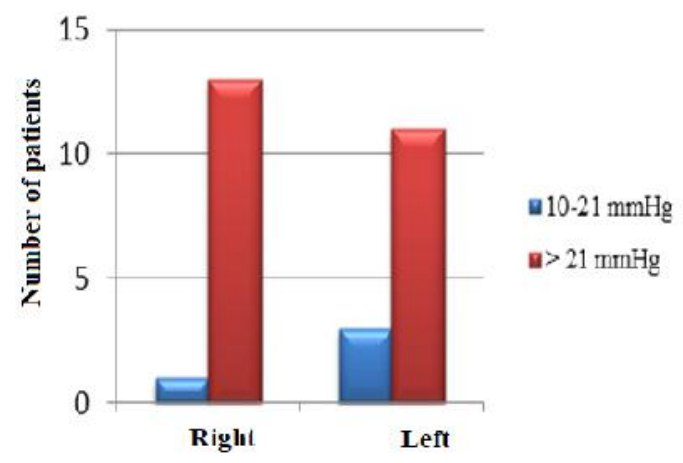

Fig. 6. Bilateral primary open angle glaucoma patients based on IOP.

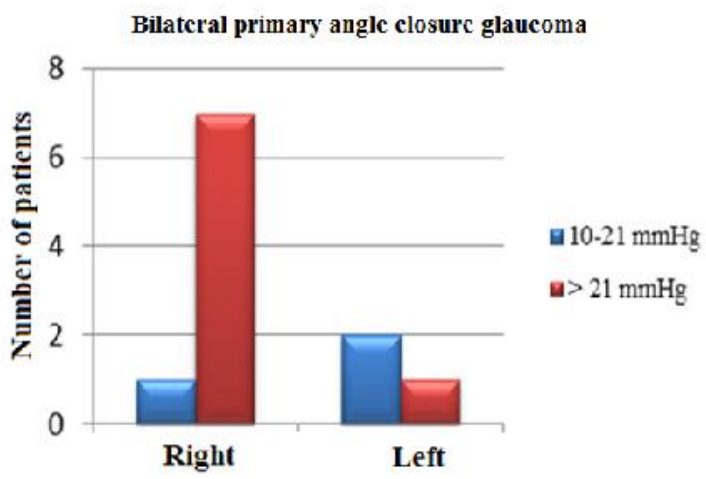

Fig. 7. Unilateral primary angle closure glaucoma patients based on IOP.

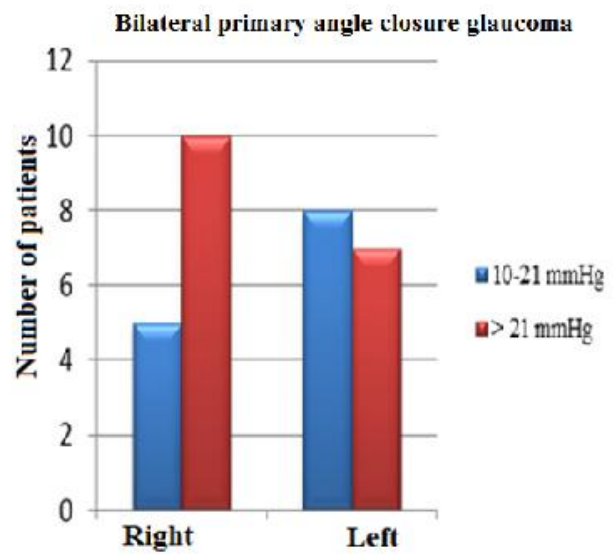

Fig. 8. Bilateral primary primary angle closed glaucoma patients based on IOP.
Based on the results of a review of Saccà et al, trabecular meshwork experiences pigmentation which is thought to be due to the associated changes in the posterior iris surface. This causes an obstacle to discharging into the trabecular meshwork, a process that is thought to be related to an increase in the juxtacanalicular connective tissue. Aging also causes changes in trabecular meshwork fibers which, in younger age, have a parallel pattern. In addition, increa-sing age is also associated with a reduced number of large vacuoles and intracellular pores in Schlemm's canal (Saccà et al 2016).

Lens factors also affect the occurrence of glaucoma in old age. According to Markowitz \& Morin (1984), lens thickness increased in the fourth and sixth decades, then there was no increase for about a decade, and finally increased again but at a slower rate. The prevalence of primary angle closure increases in the age 40s. This is due to an increase in lens thickness and more forward movements of the lens along with age that can cause iridolenticular contact (American Academy of Ophthalmology Staff 2016).

From the study, the data on the number of lateralities in primary open angle glaucoma were mostly bilateral $(66.7 \%)$, and so was in primary angle closure glaucoma $(57.7 \%)$. A previous study conducted in Nepal, which obtained data from 9 subjects, there were 2 subjects who experienced bilateral blindness (Thapa et al 2012) and in Mongolia there were 27 subjects experienced unilateral blindness, while 12 subjects had bilateral blindness (Song et al 2011) However, in these two studies there was no information on the number of subjects with unilateral or bilateral glaucoma. Primary open-angle glaucoma usually occurs bilaterally but has a different degree of severity in each eye (American Academy of Ophthalmology Staff 2016).

Of the 76 eyes affected by glaucoma, the visual acuity was mostly mild vision loss and near-total vision loss $(22.4 \%)$ and the least was moderate vision loss $(3.9 \%)$. The high blindness rate in glaucoma patients may be because the patients are too late to seek for treatment due to the ignorance to the illness or lack of the compliance in using glaucoma drugs. In addition, according to Tehrani (2014), glaucoma is the most common cause of irreversible blindness. So, if someone has experienced visual acuity or narrowing of the visual field due to glaucoma, the therapy given is only aimed at maintaining the vision that still exists and so as not to get worse, not to restore the visual function.

The high rate of visual impairment and blindness in this study is in accordance with research conducted in Thailand in 2003, which found that the second most 
common cause of unilateral blindness is glaucoma, which was as much as $12 \%$ (Bourne et al 2003). In addition, according to the Indonesian Ministry of Health's Data and Information Center, in 2010, glaucoma was the third largest cause of visual impairment $(2 \%)$ and the second largest cause of blindness $(8 \%)$ in the world (Ministry of Health's Data and Information Center 2014) .

Most patients with primary open-angle glaucoma can maintain sharp vision throughout their lives. Patients who have a risk of blindness are those who have experienced a decrease in visual acuity when diagnosed with glaucoma. In a recent study, the cumulative risk of unilateral and bilateral blindness in primary open-angle glaucoma was $7.4 \%$ and $3.4 \%$, respectively, after 10 years of diagnosis. The risk increased to $13.5 \%$ and 4.3\% after 20 years (American Academy of Ophthalmology Staff 2016). Of the 64 patients diagnosed with primary open angle glaucoma, after being given the best correction, 19 experienced visual impairment, including 13 patients who experienced unilateral or bilateral blindness (Ramakrishnan et al 2003). Decreased visual acuity in elderly patients can also be affected by cataracts, refractive abnormalities, Age-related Macular Degeneration (AMD), diabetes mellitus and hypertension. Further research needs to be done to find out the influence of these comorbidities on decreasing visual acuity in glaucoma patients.

IOP examination in Eye Outpatient Clinic at RA Basoeni Hospital was done using Schiotz tonometry. From this study, 47 patients were suffering from primary glaucoma, and of these 76 were exposed to glaucoma. Of these, only 22 eyes had IOP between 10 $21 \mathrm{mmHg}(28.9 \%)$ and the rest had IOP >21 $\mathrm{mmHg}$ $(71.1 \%)$. In older patients, this may be due to the patient's low adherence to the use of glaucoma medications or, perhaps when the data were taken, the patients were still diagnosed early with glau-coma. The patient may not know he has glaucoma because the PC angle closes slowly and the IOP increases gradually.

In acute angle closure glaucoma, IOP increases rapidly as a result of the relative blockade of the trabeculum tissue by the iris. During acute attacks, IOP elevation is sufficient to cause glaucomatous damage to the optic nerve, nerve ischemic damage, and/or retinal vascular obstruction. PAS can occur quickly and intraocular pressure (IOP)-induced ischemia can cause sectoral atrophy in the iris and the release of the pigment (American Academy of Ophthalmology Staff 2016).

If the synechiae persists, chronic angle closure may follow the acute angle closure. This can also occur if the PC angle closes slowly and the IOP increases gradually because the PC angle function is increasingly disturbed. Due to gradual and asymptomatic PC angle narrowing, chronic angle closure is finally formed. This disease tends to be diagnosed at an advanced stage and is a major cause of blindness in Asia. At the chronic primary angle closure, peripheral anterior synechiae (PAS) is formed slowly. The cause of this phenomenon is uncertain, but there is evidence of several mechanisms involved, such as pupillary block, abnormal thickness and iris position, as well as iris plateau configuration (American Academy of Ophthalmology Staff 2016).

\section{CONCLUSION}

The most common type of primary glaucoma experienced by a patient is primary angle closure glaucoma. In primary open-angle glaucoma, the number of males is almost the same as female patients. Whereas, in primary angle closure glaucoma, more female patients were found than males. Primary glaucoma patients, both open and closed, are mostly $>60$ years old. Both primary open and angle closure glaucoma mostly occur bilaterally. The highest visual acuity of primary glaucoma patients is mild vision loss and near-total vision loss. Glaucoma patients have higher IOP of $>21 \mathrm{mmHg}$ in both right and left eye. This study only examined patients in the Eye Outpatient Clinic at RA Basoeni Hospital, Mojokerto, Indonesia from January to December 2016, so that further and more complete research is needed with a larger sample population. In addition, the imple-mentation of this study was limited in time. It is necessary to provide reliable and integrated knowledge to the public about eye diseases, especially glaucoma, to increase public awareness of this disease in order to reduce the number of blindness in the community.

\section{ACKNOWLEDGMENT}

The author would like to thank Dr. Budi Samsul Fuad, $\mathrm{Sp} . \mathrm{M}$ as a supervisor for his direction and guidance, $\mathrm{dr}$. Endang Sulistyowati, MM. Kes as the director of RA Basoeni Hospital Mojokerto, Indonesia, who had given permission to the author to conduct this study, the optical refractionists, the medical record employees, and all parties who helped the author to complete this study.

\section{REFERENCES}

Agarwal R, et al (2009). Current concepts in the pathophysiology of glaucoma. Indian J Ophthalmol 57, 257266 
American Academy of Ophthalmology Staff (2016). Basic and clinical science course: Glaucoma. San Fransisco, AAO

Bourne R, et al (2003). Prevalence of glaucoma in Thailand: A population based survey in Rom Klao District, Bangkok. Br J Ophthamol 87, 1069-1074

Cheng JW, et al (2014). The prevalence of primary angle closure glaucoma in adult Asians: A systematic review and meta-analysis. Plos One 9, 1-9

Ilyas S, et al (2002). Ilmu penyakit mata untuk dokter umum dan mahasiswa kedokteran. Jakarta, Sagung Seto

Klein BE, et al (1992). Prevalence of glaucoma. The Beaver Dam Eye Study. Ophthalmology 99, 1499. 1504

Markowitz SN, Morin JD (1984). Angle-closure glaucoma: Relation between lens thickness, anterior chamber depth and age. Can J Ophthalmol 19, 300-2

Ministry of Health's Data and Information Center (2014). Situasi gangguan penglihatan dan kebutaan. Jakarta, Kementerian Kesehatan RI

Ramakrishnan R et al (2003). Glaucoma in a rural population of Southern India: The aravind comprehensive eye survey. Ophthalmology 110, 1484-1480
Riordan-Eva P, John W (2009). Vaughan \& Ashbury: Oftalmologi Umum. Jakrta: ECG

Saccà SC, et al (2016). From DNA damage to functional changes of the trabecular meshwork in aging and glaucoma. Ageing Research Reviews. http://dx.doi.org/10.1016/j.arr.2016.05.012. Accessed August 17, 2017

Song W, et al (2011). Prevalence of glaucoma in a rural Northern China adult population a population-based survey in Kailu County, Inner Mongolia. Ophthalmology 118, 1982-1988

Thapa SS, et al (2012). A population-based survey of the prevalence and types of glaucoma in Nepal: The Bhaktapur glaucoma study. Ophthalmolgy 9, 759-764

Tehrani S (2014). Gender Difference in the pathophysiology and treatment of glaucoma. Current Eye Research 40, 191-200

Tielsch JM, et al (1991). Racial variations in the prevalence of primary open-angle glaucoma. The Baltimore Eye Survey. JAMA 266, 369-374

WHO (2014). Visual impairment and blindness. Available from http://www.who.int/mediacentre/factsheets/ fs282/en/. Accessed August 15, 2017 